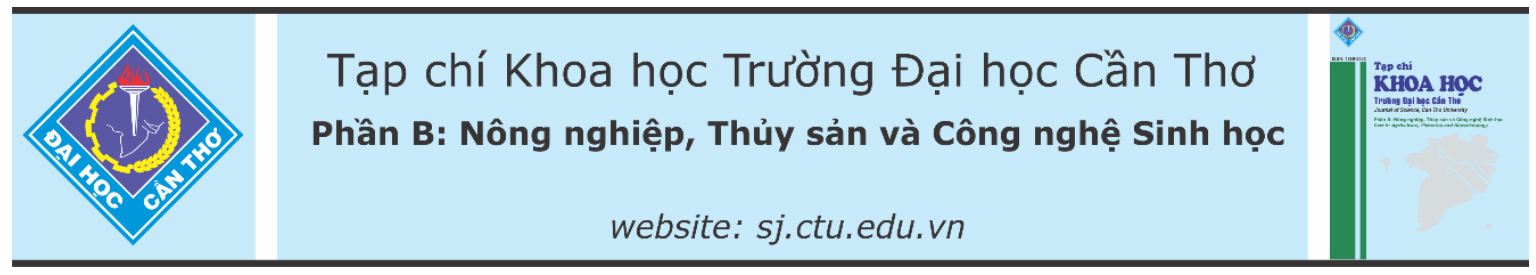

DOI:10.22144/ctu.jvn.2021.047

\title{
ẢNH HƯởNG CỦA NGUỒN CÁ BỐ MẸ VÀ KÍCH CÕ̃ BAN ĐÂU ĐẾN TĂNG TRƯỞNG CỦA CÁ TRÊ VÀNG (Clarias macrocephalus) GIỐNG
}

\author{
Dương Thúy Yên ${ }^{1 *}$, La Nghĩa Lê Thanh ${ }^{2}$, Huỳnh Thị Trúc Ly ${ }^{3}$ và Nguyễn Thị Ngọc Trân ${ }^{1}$ \\ ${ }^{1}$ Khoa Thủy sản, Truờng Đại học Cần Tho \\ ${ }^{2}$ Lớp Nuôi trồng thủy sản K42, Khoa Thủy sản, Trường Đại học Cần Tho' \\ ${ }^{2}$ Lớp Cao học Nuôi trồng thủy sản K25, Khoa Thủy sản, Truờng Đại học Cần Tho \\ *Người chịu trách nhiệm về bài viết: Dương Thúy Yên (email: thuyyen@ctu.edu.vn)
}

\section{Thông tin chung:}

Ngày nhận bài: 22/08/2020

Ngày nhận bài sủa: 21/09/2020

Ngày duyệt đăng: 28/04/2021

Title:

Effects of broodstock origin and the initial size on growth and survival rates of bighead catfish (Clarias

macrocephalus) fingerlings

\section{Tù khóa:}

Cá trê vàng, kích cõ̃, nguồn bố mẹ, tăng trương, tỉ lệ sống

\section{Keywords:}

Broodstock sources, Clarias macrocephalus, growth, size, survival

\begin{abstract}
The study was aimed to evaluate effects of broodstock origin and offspring's initial size on the growth and survival rates of bighead catfish (Clarias macrocephalus) fingerlings to provide information for a breeding program of the species. Three treatments of fingerlings were produced from three sources, including wild broodstock in Ca Mau and Hau Giang, and cultured fish in Can Tho. Fish was cultured in $500 \mathrm{~L}$ - tanks of a recirculating system and fed with commercial pellet (containing $40 \%$ protein). Each fish source was divided into two initial sizes and designed into four replicates, except three replicates for Can Tho source. After two months, weights of fish ranged 5.70-10.20 g and specific growth rates of fish were 4.94-5.28\%/day. Can Tho fingerlings had the highest growth rates. However, differences in growth parameters were not significant among three broodstock sources and were not affected by the interaction between broodstock sources and the initial sizes $(P>0.05)$. Feed conversion ratios (FCR) ranged from 0.85 (Can Tho) to 1.57 (Hau Giang). Survival rate of Can Tho fingerlings was highest (57.3\%) and Hau Giang was lowest (25.5\%). Broodstock sources and the initial sizes did not significantly affect FCR and survival rates. Generally, the offspring of bighead catfish from Can Tho source had better performance of growth and survival compared to fish from the two wild sources.
\end{abstract}

\section{TÓM TẮT}

Đề tài này thưc hiện nhằm đánh giá ảnh hwởng của nguồn cá bố mẹ và kích cõ cá con ban đầu đến tăng trưởng và tỉ lệ sống của cá trê vàng giai đoạn uoong tù hương lên giống để làm cơ sở cho chọn giống cá trê vàng. Ba nguồn cá con được sinh sản tù ba nguồn cá bố me cá tư nhiên ở Cà Mau, Hậu Giang và cá nuôi ở Cần Tho: Cá được nuôi trong bể $500 \mathrm{~L}$ được thiết kế hệ thống tuần hoàn và được cho ăn bằng thức ăn viên công nghiệp (chía 40\% đạm). Mỗi nguồn cá được bố trí với kích cỡ ban đầu khác nhau trong tổng số 4 là̀n lạ̣p lại, riêng nguồn cá Cần Tho được lạ̣p lại 3 lần. Sau 2 tháng nuôi, khối luợng trung bình của cá ở các nghiệm thức dao động tù 5,70$10,20 \mathrm{~g}$ và tốc độ tăng truơơng đặc thù (SGR) đạt 4,94-5,28\%/ngày. Cá Cần Tho có tốc độ tăng truơơng cao nhất, tuy nhiên, sư khác biệt về các chỉ tiêu tăng trưởng giữa các nghiệm thức không có ýnghĩa thống kê (P>0,05). Hệ số thức ăn (FCR) dao động tù̀ 0,85 (Cần Tho) đến 1,57 (Hậu Giang). Tỉ lệ sống cao nhất ở cá Cần Tho (57,3\%) và thấp nhất ở cá Hậu Giang (25,5\%). Song, nguồn cá và kích cỡ ban đầu không ảnh huớng có ýnghĩa thống kê đối với FCR và tỉ lệ sống. Nhìn chung, nguồn cá nuôi Cần Tho có tăng trưởng và tỉ lẹ sống tốt hơn so với hai nguồn cá tự nhiên. 


\section{GIỚI THIỆU}

Trong cùng một loài, cá có nguồn gốc (quần thể hay dòng) khác nhau thì thể hiện khác nhau ở nhiều đặc điểm (Dunham, 2011). Ở cá nheo Mỹ (Italurus punctatus), dòng cá ảnh hưởng đến tăng trưởng, khả năng kháng bệnh, tuổi thành thục, sức sinh sản,...(Dunham \& Smith, 1985, trích bởi Dunham et al., 2001). Nguồn gốc cá bố mẹ cũng ảnh hưởng đến tăng trưởng và sự phân ly màu sắc ở đàn con của cá rô phi đỏ Oreochromis sp. (Hulata et al., 1995). Cá rô đồng (Anabas testudineus) (Dương Thúy Yên \& Dương Nhựt Long, 2013) hay cá sặc rằn (Trichopodus pectoralis) (Nguyễn Hoàng Thanh và ctv., 2019) có tốc độ tăng trưởng khác nhau giữa nguồn cá nuôi và cá tự nhiên. Do ảnh hưởng của nguồn gốc cá bố mẹ đến tăng trưởng của đàn con phổ biến ở nhiều loài cá nên đánh giá dòng được xem là biện pháp đầu tiên để chọn ra nguồn cá tốt cho các chương trình chọn giống cá (Dunham, 2011).

Cá trê vàng (Clarias macrocephalus) có giá trị kinh tế cao và là đối tượng quan trọng cần áp dụng chương trình chọn giống bởi chúng có tốc độ tăng trưởng và tỉ lệ sống tương đối chậm so với các loài cá nuôi khác. Bên cạnh đó, quá trình thuần hóa lâu trong điều kiện trại giống trên 30 năm (Duong \& Scribner, 2018), một mặt tạo nên dòng cá thích nghi tốt với điều kiên nuôi, nhưng mặt khác có thể dòng cá bị ảnh hưởng của suy thoái cận huyết và biến đổi di truyền ngẫu nhiên (Tave, 1999). Để kiểm chứng giả thuyết trên và chọn nguồn cá cho chương trình chọn giống cá trê vàng, một số nghiên cứu ban đầu đã đánh giá ảnh hưởng của nguồn bố mẹ nuôi và tự nhiên khác nhau đến biểu hiện của đàn con (Dương Thúy Yên và ctv., 2020). Ở giai đoạn ương từ cá bột lên cá giống, cá có nguồn gốc cá bố mẹ từ trại giống tăng trưởng nhanh hơn nhưng khác biệt không có ý nghĩa so với cá có nguồn gốc bố mẹ từ tự nhiên . Tuy nhiên, trong cùng một nguồn cá, kể cả trong cùng một bể ương, cá có sự phân hóa sinh trưởng lớn, dẫn đến sự chênh lệch lớn trong cùng một nghiệm thức. Vì vậy, ảnh hưởng của kích cỡ cần được chú ý trong ương cá trê vàng.

Nghiên cứu này tiếp tục đánh giá ảnh hưởng của nguồn cá bố mẹ nuôi và tự nhiên, đồng thời xem xét ảnh hưởng của kích cỡ cá ban đầu đối với tăng trưởng và tỉ lệ sống của cá trê vàng giai đoạn ương giống, nhằm bổ sung thông tin cho chương trình chọn giống cá trê vàng.

\section{PHƯƠNG PHÁP NGHIÊN CÚU}

\subsection{Nguồn cá thí nghiệm}

Nguồn cá bố mẹ gồm một nguồn cá nuôi và hai nguồn cá thu từ tự nhiên. Cá nuôi được thu từ trại giống ở Cần Thơ $(\mathrm{CT})$. Cá tự nhiên được thu ở vườn Quốc gia U Minh Hạ, Cà Mau $(\mathrm{CM})$ và khu bảo tồn Lung Ngọc Hoàng, Hậu Giang (HG). Cá đã được nuôi vỗ 3 tháng trong hệ thống tuần hoàn trước khi cho sinh sản nhân tạo.

Mỗi nguồn cá được cho sinh sản 16 đến 18 cặp. Cá bột sau khi nở được gom theo nghiệm thức (nguồn cá) và ương nuôi trong cùng điều kiện đến 2 tháng (cá giống). Khi đó, cá giống được sử dụng trong thí nghiệm này.

\subsection{Bố trí thí nghiệm}

Hệ thống thí nghiệm: thí nghiệm được thực hiện ở trên bể composite với thể tích mỗi bể $500 \mathrm{~L}$ (chứa $400 \mathrm{~L}$ nước) được thiết kế trong hệ thống tuần hoàn. Trước khi thí nghiệm, bể composite được xử lý bằng chlorin và rửa sạch, sau đó vận hành hệ thống tuần hoàn một tuần trước khi thả cá.

Bố trí thí nghiệm: trong cùng một nghiệm thức, cá có kích cỡ khác nhau được chia làm hai nhóm (cá lớn và cá nhỏ), mỗi nhóm gồm những cá thể tương đối đều cỡ và mỗi nghiệm thức có 4 lần lặp lại (Bảng 1). Riêng nghiệm thức $\mathrm{CT}$, sau khi bố trí cá bị chết 1 bể nên chỉ còn 3 lần lặp lại. Cá được ương với mật độ thả 300 con/bể. Thời gian thí nghiệm là 2 tháng.

Bảng 1. Nguồn cá thí nghiệm, kích cỡ cá và số lần lặp lại ở các nghiệm thức

\begin{tabular}{lcc}
\hline \multirow{2}{*}{ Nguồn cá } & \multicolumn{2}{c}{ Kích cỡ cá (số lần lặp lại) } \\
\cline { 2 - 3 } & Cá lớn $(\mathbf{g})$ & Cá nhỏ $(\mathbf{g})$ \\
\hline Cà Mau $(\mathrm{CM})$ & $0,38(2$ lần $)$ & $0,18(2$ lần $)$ \\
Cần Thơ $(\mathrm{CT})$ & $0,44(2$ lần $)$ & $0,22(1$ lần $)$ \\
Hậu Giang $(\mathrm{HG})$ & 0,23 (2 lần) & $0,16(2$ lần $)$ \\
\hline
\end{tabular}

\subsection{Cho ăn, chăm sóc và quản lý}

Cá được cho ăn thức ăn công nghiệp (nhãn hiệu Việt Thắng), loại viên nổi, dạng nhỏ vừa với kích cỡ miệng cá (thay đổi từ $0,6-1 \mathrm{~mm}$ ). Thức ăn có hàm lượng đạm $40 \%$ và được cho cá ăn 4 lần/ngày (vào lúc $7 \mathrm{~h} 30,11 \mathrm{~h}, 14 \mathrm{~h} 30$ và $17 \mathrm{~h} 30$ ) với lượng cho ăn theo nhu cầu của cá. Thức ăn được cân trước khi cho ăn và cân lại thức ăn thừa để theo dõi lượng thức ăn sử dụng.

Các bể cá được sục khí nhẹ để đảm bảo đủ oxy hòa tan cho cá phát triển. Mỗi ngày, xả cặn ở bể lắng và bơm bù lại lượng nước mới. Giai đoạn này thường xuyên theo dõi biểu hiện sức khỏe của cá. Những ngày mưa, giảm số lần và lượng cho ăn. 


\subsection{Các chỉ tiêu theo dõi}

Các yếu tố môi trường: nhiệt độ được đo 2 lần/ngày ( $8 \mathrm{~h}$ và $14 \mathrm{~h})$ bằng nhiệt kế. Oxy và $\mathrm{pH}$ được đo 3 ngày/lần bằng máy đo hiệu HANA.

Chỉ tiêu tăng trưởng: khối lượng ban đầu của cá được tính trung bình từ lượng cân tổng cho mỗi bể chia cho số con (300 con). Khi kết thúc thí nghiệm sau 2 tháng, cá được cân tổng khối lượng và đếm số con để tính khối lượng trung bình của cá cuối thí nghiệm. Đồng thời, mỗi bể được thu ngẫu nhiên 30 cá thể và cân từng con (bằng cân điện tử có độ sai số $0,01 \mathrm{~g}$ ) để tính sự phân hóa sinh trưởng.

\subsection{Các chỉ tiêu tính toán}

Tỉ lệ sống (survival rate - SR) được xác định sau khi kết thúc thí nghiệm bằng cách đếm số cá còn lại ở mỗi bể so với số cá ban đầu:

$$
\mathrm{SR}(\%)=\frac{\text { Số cá thu hoạch }}{\text { Số cá } t h a ̉} x 100
$$
DWG)

Tăng trưởng tuyệt đối ngày (Daily weight gain -

$$
\text { DWG }(\mathrm{g} / \text { ngày })=\left(\mathrm{W}_{\mathrm{f}}-\mathrm{W}_{\mathrm{i}}\right) / \mathrm{T}
$$

Tốc độ tăng trưởng đặc thù (Specific growth rate $-\mathrm{SGR})$

$$
\operatorname{SGR}(\% / \text { ngày })=\frac{\ln (W f)-\ln (W i)}{\mathrm{T}} \times 100
$$

Trong đó:

$\mathrm{W}_{\mathrm{f}}$ : khối lượng cuối; $\mathrm{W}_{\mathrm{i}}$ : khối lượng ban đầu;

T: thời gian nuôi

Hệ số thức ăn (food conversion ratio - FCR)

$$
F C R=\frac{\text { khối lượng thức ăn cho ăn }}{\text { tăng trọng của cá }}
$$

Thức ăn được cân trước khi cho ăn và cân lại thức ăn thừa sau khi cho ăn để điều chỉnh. Số cá chết được ghi nhận hàng ngày để tính lượng thức ăn chính xác.

Sự phân hóa sinh trưởng được đánh giá thông qua hệ số biến động (coefficient variation - CV)

$$
\mathrm{CV}=\frac{\text { Độ lêch chuẩn }}{\text { Khối lượg trung bình }} \times 100
$$

Độ lệch chuẩn và khối lượng trung bình được tính từ các cá thể trong cùng một bể.

Sự phân hóa sinh trưởng còn được đánh giá dựa trên tỉ lệ các nhóm khối lượng cá khi thu hoạch (dựa trên khối lượng của từng cá thể) và so sánh giữa các nghiệm thức.

\subsection{Phương pháp xử lý số liệu}

Tỉ lệ sống của cá được chuyển đổi logarit tự nhiên $(\operatorname{Ln}(\mathrm{SR}))$ trước khi phân tích thống kê (Warton \& Hui, 2011). Sự khác biệt về các chỉ tiêu tăng trưởng, $\mathrm{FCR}$ và $\mathrm{Ln}(\mathrm{SR})$ của 3 nguồn cá với hai nhóm kích cỡ ban đầu được kiểm định bằng phương pháp phân tích ANOVA hai nhân tố. Phép thử Duncan được áp dụng khi ảnh hưởng của nguồn cá có ý nghĩa thống kê, ở mức ý nghĩa 0,05 . Số liệu được phân tích bằng phần mềm SPSS 20.0.

\section{KẾT QUẢ}

\subsection{Các yếu tố môi trường}

Kết quả theo dõi các yếu tố môi trường cho thấy nhiệt độ trung bình buổi sáng khoảng $25,2-28,8^{\circ} \mathrm{C}$, buổi chiều $25,7-31,8^{\circ} \mathrm{C}$; $\mathrm{pH}$ dao động từ $6,8-8,4$; hàm lượng oxy hòa tan từ 5,1-6,9 mg/L (Bảng 2).

Bảng 2. Các yếu tố môi trường trong thí nghiệm

\begin{tabular}{lrrr}
\hline Nghiệm thức & $\mathbf{p H}$ & $\begin{array}{r}\text { Nhiệt độ } \\
\left(\mathbf{(}^{\mathbf{C}} \mathbf{C}\right)\end{array}$ & $\begin{array}{r}\text { Oxy hòa } \\
\mathbf{t a n}(\mathbf{m} / \mathbf{L})\end{array}$ \\
\hline Cà Mau & $6,9-8,4$ & $25,2-31,8$ & $5,2-6,6$ \\
Cần Thơ & $6,9-8,2$ & $25,2-30,1$ & $5,1-6,1$ \\
Hậu Giang & $6,8-8,0$ & $25,4-30,6$ & $5,1-6,9$ \\
\hline
\end{tabular}

Nhìn chung, các yếu tố nhiệt độ và pH có biến động nhỏ trong thời gian thí nghiệm và không có sự chênh lệch giữa các bể hay giữa các nghiệm thức. Khoảng dao động của các yếu tố trên trong khoảng thích hợp cho sự phát triển của cá trê vàng.

\subsection{Tăng trưởng của ba nguồn cá trê vàng giai đoạn giống}

Cá ban đầu có khối lượng khác nhau, trong đó cá lớn nhất là nguồn cá $\mathrm{CT}$ và thấp nhất là nguồn cá HG (Bảng 1 và 3 ). Sau 60 ngày, các chỉ tiêu tăng trưởng khác biệt không có ý nghĩa $(\mathrm{P}>0,05)$ giữa các nguồn cá và không chịu ảnh hưởng bởi sự tương tác giữa nguồn cá và kích cỡ ban đầu (Bảng 3 ). Tuy nhiên, ảnh hưởng của kích cỡ ban đầu khi bố trí thí nghiệm đến các chỉ tiêu tăng trưởng của cá là có ý nghĩa $(\mathrm{P}<0,05)$ : cá ban đầu lớn hơn có tốc độ tăng trưởng (DWG và $\mathrm{SGR}$ ) cao hơn so với cá nhỏ. Xu hướng này thể hiện ở cả ba nguồn cá. Ví dụ, ở nguồn cá $\mathrm{CT}$, cá cỡ lớn có $\mathrm{DWG}$ là $0,22 \mathrm{~g} /$ ngày và $\mathrm{SGR}$ là $5,60 \% /$ ngày, trong khi $\mathrm{DWG}$ và SGR tương ứng ở cá nhỏ là $0,05 \mathrm{~g} /$ ngày và $4,50 \pm 0,60 \% /$ ngày.

Mặc dù các chỉ tiêu tăng trưởng khác biệt không có ý nghĩa thống kê giữa các nghiệm thức, nhưng nguồn cá nuôi $\mathrm{CT}$ có khối lượng trung bình khi kết thúc thí nghiệm $(10,20 \pm 7,70 \mathrm{~g})$ cao hơn so với hai nguồn cá tự nhiên $\mathrm{HG}(6,75 \pm 6,29 \mathrm{~g})$ và $\mathrm{CM}$ $(5,70 \pm 2,68 \mathrm{~g})$. Tốc độ tăng trưởng tuyệt đối về khối 
lượng theo ngày (DWG) ở các nghiệm thức dao động $0,09-0,16 \mathrm{~g} /$ ngày và cao nhất là ở cá $\mathrm{CT}$ $(0,16 \pm 0,13 \mathrm{~g} /$ ngày). Tuy nhiên, khi xét về tốc độ tăng trưởng đặc thù (SGR), sự chênh lệch SGR giữa
3 nghiệm thức là rất nhỏ, dao động từ 4,94 \%/ngày (cá $\mathrm{CM}$ ) đến $5,28 \% /$ ngày (cá $\mathrm{HG}$ ) và không có ý nghĩa thống kê $(\mathrm{P}>0,05)$.

Bảng 3. Các chỉ tiêu tăng trưởng của cá trê vàng ở giai đoạn giống

\begin{tabular}{|c|c|c|c|c|c|c|}
\hline Nguồn cá & Cõ̃ cá & $\mathrm{W}_{0}(\mathrm{~g})$ & $\mathrm{W}_{60}(\mathrm{~g})$ & DWG (g/ngày) & SGR (\%/ngày) & FCR \\
\hline \multirow{2}{*}{ Cà Mau } & Cá lớn & 0,38 & $7,67 \pm 1,20$ & $0,12 \pm 0,02$ & $4,99 \pm 0,26$ & $1,06 \pm 0,26$ \\
\hline & Nhỏ & $0,18 \pm 0,01$ & $3,76 \pm 2,15$ & $0,06 \pm 0,04$ & $4,90 \pm 0,90$ & $1,03 \pm 0,16$ \\
\hline \multicolumn{2}{|c|}{ Trung bình chung } & $0,28 \pm 0,11^{\mathrm{b}}$ & $5,70 \pm 2,68^{\mathrm{a}}$ & $0,09 \pm 0,04^{\mathrm{a}}$ & $4,94 \pm 0,54^{\mathrm{a}}$ & $1,04 \pm 0,18^{\mathrm{a}}$ \\
\hline \multirow{2}{*}{ Cần Thơ } & Cá lớn & 0,44 & $13,66 \pm 6,82$ & $0,22 \pm 0,11$ & $5,60 \pm 0,87$ & $0,76 \pm 0,12$ \\
\hline & Nhỏ & 0,22 & 3,27 & 0,05 & 4,50 & 1,02 \\
\hline \multicolumn{2}{|c|}{ Trung bình chung } & $0,37 \pm 0,13^{\mathrm{c}}$ & $10,20 \pm 7,70^{\mathrm{a}}$ & $0,16 \pm 0,13^{\mathrm{a}}$ & $5,23 \pm 0,88^{\mathrm{a}}$ & $0,85 \pm 0,17^{\mathrm{a}}$ \\
\hline \multirow{2}{*}{ Hậu Giang } & Cá lớn & 0,23 & $11,56 \pm 4,94$ & $0,19 \pm 0,08$ & $6,47 \pm 0,73$ & $0,84 \pm 0,08$ \\
\hline & Nhỏ & 0,16 & $1,87 \pm 0,13$ & $0,03 \pm 0,00$ & $4,09 \pm 0,12$ & $2,30 \pm 1,03$ \\
\hline \multicolumn{2}{|c|}{ Trung bình chung } & $0,19 \pm 0,04^{\mathrm{a}}$ & $6,75 \pm 6,29^{\mathrm{a}}$ & $0,11 \pm 0,10^{\mathrm{a}}$ & $5,28 \pm 1,44^{\mathrm{a}}$ & $1,57 \pm 1,03^{\mathrm{a}}$ \\
\hline \multicolumn{7}{|c|}{ Giá trị $P$} \\
\hline \multicolumn{2}{|c|}{ Nguồn cá (NC) } & $<0,01$ & 0,69 & 0,70 & 0,77 & 0,24 \\
\hline \multirow{2}{*}{\multicolumn{2}{|c|}{ Cỡ cá ban đầu $(\mathrm{C})$}} & $<0,01$ & 0,02 & 0,02 & 0,03 & 0,12 \\
\hline $\mathrm{NC} * \mathrm{C}$ & & $<0,01$ & 0,52 & 0,51 & 0,14 & 0,17 \\
\hline
\end{tabular}

Ghi chú: Giá trị trung bình chung của mỗi chỉ tiêu ở ba nghiệm thức theo sau bởi các chũ cái giống nhau thì khác biệt không có ý nghĩa thống kê $(P>0,05)$.

W: khối luợng; DWG: Tăng truởng tuyệt đối ngày; SGR: Tốc độ tăng truởng đặc thù; FCR: Hệ số thức ăn

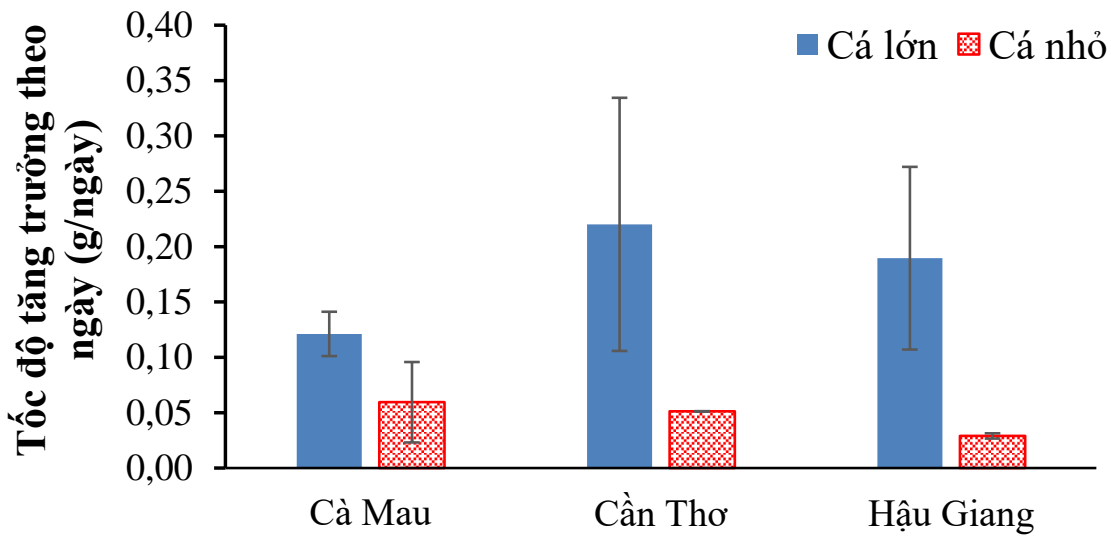

\section{Nguồn cá}

Hình 1. Tốc độ tăng trưởng theo ngày của ba nguồn cá trê giai đoạn giống

\subsection{Hệ số thức ăn (FCR)}

Hệ số thức ăn (Bảng 3) khác biệt không có ý nghĩa thống kê giữa các nghiệm thức $(\mathrm{P}>0,05)$. Tuy nhiên, nguồn cá $\mathrm{CT}$ có $\mathrm{FCR}(0,85 \pm 0,17)$ thấp hơn so với cá $\mathrm{CM}(1,04 \pm 0,18)$ và $\mathrm{HG}(1,57 \pm 1,03)$. Nguồn cá $\mathrm{HG}$ có hệ số thức ăn cao và dao động lớn do ở một bể cá nhỏ, cá bị bệnh và tỉ lệ sống thấp, những cá thể còn sống tăng trưởng chậm dẫn đến FCR cao.

\subsection{Sự phân hóa sinh trưởng}

Sau 60 ngày nuôi, cá có sự phân đàn lớn thể hiện qua hệ số biến động ở 2 nhóm khối lượng (Hình $2 \mathrm{~A}$ ) và tỉ lệ phân nhóm khối lượng (Hình $2 \mathrm{~B}$ ) của 3 nguồn cá. Ẩnh hưởng của nguồn cá và kích cỡ đến hệ số biến động $(\mathrm{CV})$ không có ý nghĩa thống kê $(\mathrm{P}>0,05)$. Giá trị $\mathrm{CV}$ tương đương nhau giữa 3 nguồn cá, dao động từ 98-107\% ở nhóm cá lớn và 95-115\% ở nhóm cá nhỏ (Hình 2A). Về sự phân nhóm kích cỡ, trong cả ba nguồn cá, nhóm cá có khối lượng từ 1 đến $8 \mathrm{~g}$ chiếm tỉ lệ cao nhất (từ $44 \%$ ở cá $\mathrm{CT}$ và $\mathrm{HG}$ đến $55 \%$ ở cá $\mathrm{CM}$ ). Tuy nhiên, trong mỗi bể nuôi đều có cá thể vượt đàn, cá có khối lượng $>32 \mathrm{~g}$ chiếm $16,7 \%$ ở nguồn cá $\mathrm{CT}, 8,9 \%$ ở cá $\mathrm{HG}$ và $2,9 \%$ ở nguồn cá $\mathrm{CM}$ (Hình $2 \mathrm{~B}$ ). 

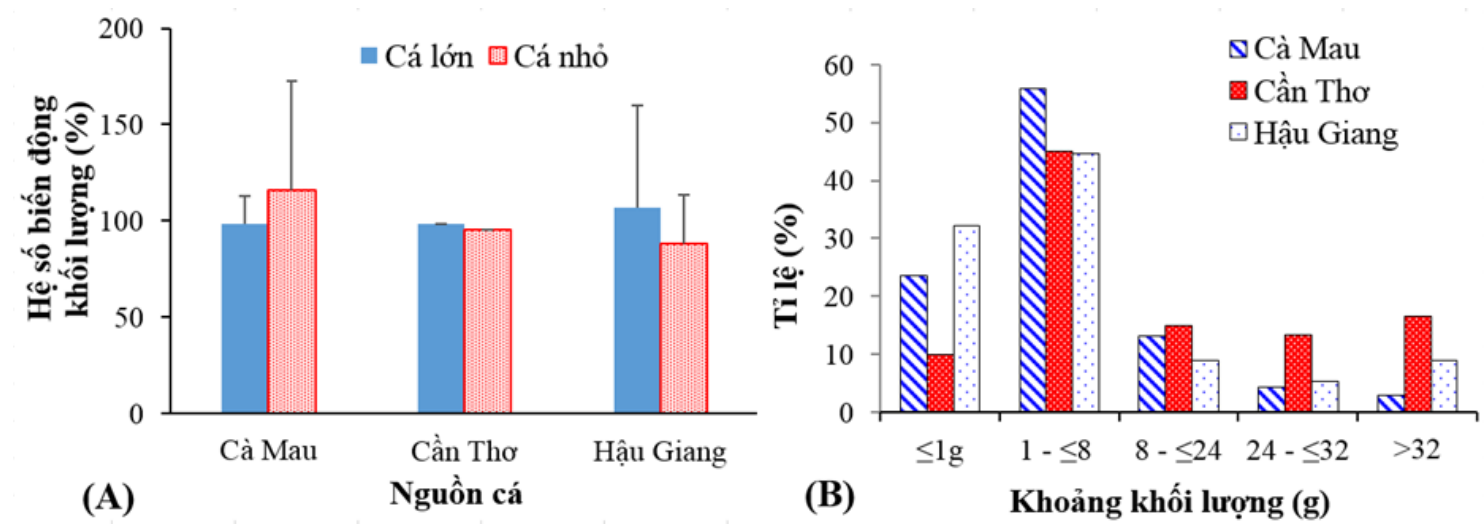

Hình 2. Hệ số biến động $(\mathrm{A})$ và tỉ lệ phân nhóm khối lượng $(\mathrm{B})$ của cá trê vàng

\subsection{Tỉ lệ sống}

Tỉ lệ sống của cá trê vàng khác biệt không có ý nghĩa thống kê giữa nguồn cá hay kích cỡ ban đầu và không phụ thuộc vào sự tương tác của hai yếu tố này $(\mathrm{P}>0,05)$. Tuy nhiên, giá trị trung bình tỉ lệ sống ở hai nhóm kích cỡ của nguồn cá $\mathrm{CT}$ là 57,3 $\pm 17,0 \%$, cao hơn so với cá $\mathrm{CM}: 35,3 \pm 21,0 \%$ và $\mathrm{HG}$ : $25,5 \pm 15,2 \%$. Trong cùng một nguồn cá và cùng nhóm kích cỡ ban đầu, tỉ lệ sống dao động lớn ở các bể, như ở nguồn cá lớn CM và CT (Hình 3).

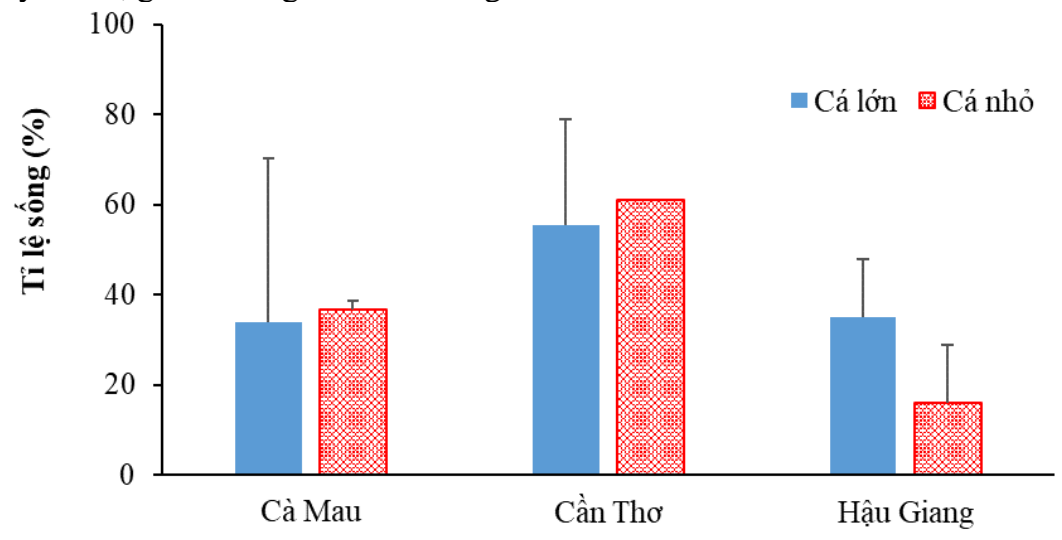

Nguồn cá

Hình 3. Tỉ lệ sống của cá trê vàng

\section{THẢO LUẬN}

Kết quả nghiên cứu cho thấy cá trê vàng từ nguồn cá nuôi CT cho kết quả tăng trưởng, hệ số thức ăn và tỉ lệ sống tốt hơn so với hai nguồn cá tự nhiên $C M$ và $H G$, mặc dù sự khác biệt các chỉ tiêu trên giữa các nguồn cá không có ý nghĩa thống kê. Trong cùng một nguồn cá và cùng nhóm kích cỡ, tăng trưởng của cá chênh lệch lớn giữa các bể ương. Ví dụ DWG ở nhóm cá lớn nguồn CT ở 2 bể (2 lần lặp lại) là 0,30 và $0,14 \mathrm{~g} /$ ngày, dẫn đến độ lệch chuẩn lớn (Hình 1 ). Điều này đã làm giảm xác suất tìm ra sự khác biệt thống kê giữa các nghiệm thức. Dù vậy, sự chênh lệch lớn các giá trị trung bình về khối lượng (hay DWG) giữa các nguồn cá cho thấy cá nuôi $\mathrm{CT}$ tăng trưởng nhanh hơn hai nguồn cá tự nhiên $\mathrm{CM}$ và $\mathrm{HG}$.

Ở giai đoạn ương từ cá bột lên cá hương, nguồn cá $\mathrm{CT}$ và $\mathrm{HG}$ có tốc độ tăng trưởng tương đương nhau (cá sau 40 ngày đạt khối lượng trung bình 0,20 g), cao hơn nhưng không có ý nghĩa so với nguồn cá $\mathrm{CM}(0,18 \mathrm{~g})$. Như vậy, mức chênh lệch khối lượng giữa nguồn cá $\mathrm{CT}$ và hai nguồn cá tự nhiên cao hơn ở giai đoạn ương giống so với giai đoạn cá hương. Kết quả này tương tự các nghiên cứu trên các loài cá đồng khác, khi so sánh nguồn cá nuôi và cá tự nhiên cho thấy cá nuôi nhìn chung có lợi thế tăng trưởng hơn nhưng mức độ khác biệt tùy thuộc vào giai đoạn ương. Đối với cá rô, ở giai đoạn cá bột, các dòng cá rô tăng trưởng tương đương nhau nhưng càng về sau 
ở giai đoạn giống, cá rô đầu vuông (dòng cá nuôi) tăng trưởng nhanh hơn so với cá tự nhiên (Dương Thúy Yên \& Dương Nhựt Long, 2013). Cá sặc rằn giai đoạn ương từ bột lên giống đạt khối lượng cao nhất ở nguồn cá nuôi Đồng Tháp $(9,26 \pm 1,18 \mathrm{~g})$, khác biệt có ý nghĩa so với nguồn cá tự nhiên ở Kiên Giang và Cà $\mathrm{Mau}$ (trung bình lần lượt là $6,40 \mathrm{~g}$ và 4,13 g) (Nguyễn Hoàng Thanh và ctv., 2019).

Trong một nghiên cứu trước cùng nguồn cá trê nuôi $\mathrm{CT}$ và cá tự nhiên $\mathrm{CM}$, kết quả cho thấy ở 75 ngày tuổi, cá $\mathrm{CM}$ có khối lượng $(1,51 \pm 0,40 \mathrm{~g})$ lớn hơn nhưng khác biệt không có ý nghĩa so với cá CT $(1,22 \pm 0,11 \mathrm{~g})$ (Dương Thúy Yên và ctv., 2020). Trong nghiên cứu này cũng ghi nhận sự chênh lệch lớn về kích cỡ của cá giữa các bể nuôi của cùng một nguồn cá và giữa các cá thể trong cùng một bể nuôi (hiện tượng phân đàn). Đây là trường hợp thường gặp trong ương cá, đặc biệt là những loài cá có tính ăn nhau và cạnh tranh cao như cá trê vàng (Dương Thúy Yên và ctv., 2020), cá rô (Morioka et al., 2009; Dương Thúy Yên và Dương Nhựt Long, 2013), các loài cá lóc (Tran Thi Thanh Hien et al., 2017)... Trong nghiên cứu này, để hạn chế sự phân đàn trong cùng một bể nuôi, cá ban đầu đã được phân thành hai nhóm kích cỡ. Tuy nhiên, cá trê vàng vẫn phân đàn nhanh, khoảng một đến hai tuần sau khi bố trí (quan sát bể ương) và mức độ càng lớn khi cuối giai đoạn ương, dẫn đến hệ số biến động lớn (Hình 2). Sự phân nhóm kích cỡ ban đầu cho thấy cá ban đầu lớn hơn thì có tốc độ tăng trưởng (thể hiện qua các chỉ tiêu DWG và SGR) nhanh hơn. Kết quả này phù hợp với nhận định của Hopkins (1992): tốc độ tăng trưởng của cá phụ thuộc vào kích cỡ và ở giai đoạn tăng trưởng nhanh (theo dạng lũy thừa), cá lớn hơn có tốc độ tăng trưởng cao hơn. Tuy nhiên, kích cỡ ban đầu không ảnh hưởng đến hệ số thức ăn và tỉ lệ sống của cá.

Sự phân đàn không những ảnh hưởng đến kết quả tăng trưởng mà còn có thể ảnh hưởng đến tỉ lệ sống. Trong thí nghiệm này không xác định được tỉ lệ ăn nhau, do bể ương lớn ( $500 \mathrm{~L})$ nên khó quan sát. Hơn nữa, một số con chết có thể do yếu hoặc bệnh bị các con khác ăn thịt, không phân biệt được với sự ăn nhau của cá lớn với cá nhỏ. Tỉ lệ sống của cá trê vàng trong thí nghiệm này tương tự với nghiên cứu trước cùng giai đoạn ương giống, tỉ lệ sống của nguồn cá $\mathrm{CM}$ và $\mathrm{CT}$ dao động lớn giữa các bể ương, lần lượt là $27,3 \pm 11,0 \%$ và $53,5 \pm 23,0 \%$ (Dương Thúy Yên và ctv., 2020). Một nguyên nhân khác ảnh hưởng đến tỉ lệ sống không cao của cá trê vàng là do cá bị bệnh trong những ngày mưa kéo dài.
Như vậy, ngoài ảnh hưởng của nguồn cá và kích cỡ ban đầu, các chỉ tiêu tăng trưởng, tỉ lệ sống, hệ số thức ăn,... của trê vàng trong giai đoạn ương còn phụ thuộc vào yếu tố bên ngoài dẫn đến sự biến động lớn trong cùng một nghiệm thức. Vấn đề này cần được khắc phục trong các nghiên cứu tương tự, trong đó, giải pháp khả thi là tăng số lần lặp lại của mỗi nhân tố thí nghiệm.

\section{KẾT LUẬN VÀ ĐỀ XUẤT}

Nguồn cá trê vàng nuôi $\mathrm{CT}$ có tốc độ tăng trưởng và tỉ lệ sống tốt hơn so với hai nguồn cá tự nhiên $\mathrm{CM}$ và $\mathrm{HG}$. Kích cỡ ban đầu lớn thì tốc độ tăng trưởng nhanh nhưng không ảnh hưởng đến tỉ lệ sống và hệ số thức ăn. Cá trê trong giai đoạn ương giống có sự phân đàn lớn.

Nghiên cứu cần được tiếp tục để đánh giá tăng trưởng và tỉ lệ sống của cá ở giai đoạn thương phẩm, đồng thời khắc phục sự biến động của các yếu tố trên trong mỗi nghiệm thức thông qua tăng số lần lặp lại.

\section{LỜI CẢM ƠN}

Đề tài này được tài trợ bởi Dự án Nâng cấp Trường Đại học Cần Thơ VN14-P6 bằng nguồn vốn vay ODA từ Chính phủ Nhật Bản.

\section{TÀI LIẸU THAM KHẢO}

Dunham, R. A. (2011). Aquaculture and fisheries biotechnology: genetic approaches (2nd ed.). CABI Publishing.

Dunham, R., Majumdar, K., Hallerman, E., Bartley, D., Mair, G., G, H., Liu, Z., Pongthana, N., Bakos, J., Penman, D., Gupta, M., Rothlisberg, P., \& HoerstgenSchwark, G. (2001). Review of Status of Aquaculture Genetics. In R. P. Subasinghe, P. Bueno, M. J. Phillips, C. Hough, S. E. McGladdery, \& J. R. Arthur (Eds.), Technical Proceedings of the Conference on Aquaculture in the Third Millenium (pp. 137-166). http://www.fao.org/docrep/003/ab412e/ab412e03.htm

Dương Thúy Yên, Nguyễn Thanh, Tuấn, Nguyễn Văn Nghĩa và Đặng Trung Pha. 2020. Tăng trưởng của cá giống trê vàng (Clarias macrocephalus) lai giữa ba nguồn cá bố mẹ. Tạp chí Khoa học Trường Đại học Cần Thơ, 56(2), 102-109.

Duong, T.-Y., \& Scribner, K. T. (2018). Regional variation in genetic diversity between wild and cultured populations of bighead catfish (Clarias macrocephalus) in the Mekong Delta. Fisheries Research, 207, 118-125. https://doi.org/10.1016/j.fishres.2018.06.012

Dương Thúy Yên và Dương Nhựt Long. (2013). Ảnh hưởng của nguồn gốc cá bố mẹ đến tăng trưởng và tỉ lệ sống của cá rô (Anabas testudineus Bloch, 1792) giai đoạn ương từ cá bột lên cá 
giống. Tạp Chí Nông Nghiệp và Phát Triển Nông Thôn, 6, 66-72.

Hopkins, J. (1993). Reporting fish growth: the review of basics. World Aquaculture Society, 23(3), 173-17.

Hulata, G., Karplus, I., \& Harpaz, S. (1995). Evaluation of some red tilapia strains for aquaculture: growth and colour segregation in hybrid progeny. Aquaculture Research, 26(10), 765-771. https://doi.org/10.1111/j.13652109.1995.tb00869.x.

Morioka, S., Ito, S., Kitamura, S., \& Vongvichith, B. (2009). Growth and morphological development of laboratory-reared larval and juvenile climbing perch Anabas testudineus. Ichthyological Research, 56(2), 162-171.

Nguyễn Hoàng Thanh, Dương Thúy Yên và Dương Nhựt Long. (2019). So sánh tăng trưởng và tỉ lệ sống của cá sặc rằn (Trichopodus pectoralis Regan, 1910) giai đoạn ương giống từ ba nguồn cá bố mẹ. Tạp chí Khoa học Trường Đại học Cần Tho, 55(3B), 96-102.

Tave, D. (1999). Inbreeding and broodstock management. FAO fisheries technical paper 392.

Tran Thi Thanh Hien, Tam, B. M., Tu, T. L. C., \& Bengtson, D. A. (2017). Weaning methods using formulated feeds for snakehead (Channa striata and Channa micropeltes) larvae. Aquaculture Research, 48(9), 4774-4782. https://doi.org/10.1111/are.13298

Warton, D. I., \& Hui, F. K. C. (2011). The arcsine is asinine: The analysis of proportions in ecology. Ecology, 92(1), 3-10. https://doi.org/10.1890/100340.1 